\title{
Mauro Canova - Jose Vincenzo Molle, Saggi sul teatro europeo fra Medioevo e Rinascimento
}

\section{G. Matteo Roccati}

\section{(2) OpenEdition}

1 Journals

\section{Édition électronique}

URL : http://journals.openedition.org/studifrancesi/32871

DOI : 10.4000/studifrancesi.32871

ISSN : 2427-5856

Éditeur

Rosenberg \& Sellier

\section{Édition imprimée}

Date de publication : 1 décembre 2005

Pagination : 618-619

ISSN : 0039-2944

\section{Référence électronique}

G. Matteo Roccati, « Mauro Canova - Jose Vincenzo Molle, Saggi sul teatro europeo fra Medioevo e Rinascimento », Studi Francesi [En ligne], 147 (XLX | III) | 2005, mis en ligne le 30 novembre 2015, consulté le 20 avril 2021. URL : http://journals.openedition.org/studifrancesi/32871 ; DOI : https:// doi.org/10.4000/studifrancesi.32871

Ce document a été généré automatiquement le 20 avril 2021.

\section{(c)}

Studi Francesi è distribuita con Licenza Creative Commons Attribuzione - Non commerciale - Non opere derivate 4.0 Internazionale. 


\title{
Mauro Canova - Jose Vincenzo Molle, Saggi sul teatro europeo fra Medioevo e Rinascimento
}

\author{
G. Matteo Roccati
}

\section{RÉFÉRENCE}

MAURO CANOVA - JOSE VINCENZO MOLLE, Saggi sul teatro europeo fra Medioevo e Rinascimento, Alessandria, Edizioni dell’Orso («Studi e ricerche», 44), 2004, 384 pp.

Le volume rassemble quatorze études des deux auteurs, études qui ont leur centre de gravité dans le genre de la farce française tardo-médiévale, en particulier la Farce de Maistre Pierre Pathelin. Les deux premiers chapitres sont consacrés à la farce française dans les années 1440-1450 et à la Farce de Maistre Trubert et d'Antrongnart d'Eustache Deschamps. Suit une série de recherches sur Pathelin, concernant les résurgences folkloriques (le crapaud, être diabolique, en référence notamment à Decameron IV 7), l'aspect démoniaque de l'avocat, les thèmes de la confession (par le biais de la comparaison avec Decameron I 1) et du rituel judiciaire. Ce dernier thème est examiné aussi dans des textes italiens du XIV ${ }^{\mathrm{e}}$ au XVI ${ }^{\mathrm{e}}$ siècle (de Bartolo da Sassoferrato aux Mariazi da Pava). Un chapitre porte sur "mistilinguismo e creazione verbale" - les «charabias» et leur fonction linguistique, le plurilinguisme -, dans Pathelin, le Miracle de Théophile, la farce de Maistre Mimin estudiant, la sottie et l'œuvre de Rabelais. La Renaissance française est également abordée dans deux études concernant, d'une part, Rabelais et le Lazarillo de Tormes, de l'autre, Les Contens (1580-1581) de Odet de Turnèbe. Enfin, les derniers chapitres portent sur les domaines italien (Ruzante) et anglais (Shakespeare). 